PUNCHING OUT: EXPLORING JUSTIFICATIONS FOR EMPLOYMENT LAND CONVERSIONS IN THE GTA By

\author{
David Cogliano \\ H.BA, University of Toronto, 2012 \\ A Major Research Paper \\ presented to Ryerson University \\ in partial fulfillment of the requirements for the degree of \\ Master of Planning \\ in \\ Urban Development
}

Toronto, Ontario, Canada, 2014

CDavid Cogliano, 2014 


\section{AUTHOR'S DECLARATION}

I hereby declare that I am the sole author of this MRP. This is a true copy of the MRP, including any required final revisions.

I authorize Ryerson University to lend this MRP to other institutions or individuals for the purpose of scholarly research.

I further authorize Ryerson University to reproduce this MRP by photocopying or by other means, in total or in part, at the request of other institutions or individuals for the purpose of scholarly research.

I understand that my MRP may be made electronically available to the public. 


\title{
PUNCHING OUT: EXPLORING JUSTIFICATIONS FOR EMPLOYMENT LAND CONVERSIONS IN THE GTA
}

\author{
CDavid Cogliano 2014 \\ Master of Planning \\ in \\ Urban Development \\ Ryerson University
}

\begin{abstract}
The current planning framework in the Province of Ontario is based on principles of "smart growth" including transit oriented development, intensification, and a focus on building complete communities. While the advancement of these principles has been positive in certain cases, the literature identifies that industrial lands may face redevelopment pressure as smart growth principles are adopted. This paper provides the opportunity to assess the extent of which this is the case in the context of the City of Markham. A content analysis of twelve employment land conversion applications provides for an on-the-ground case study of how the planning framework in Ontario, informed by smart growth principles, is leveraged by developers to support employment land conversions. Research findings include conflicting interpretations, among stakeholders, of planning policy goals related to employment land. Recommendations include the need for a more consistent articulation of policy goals and a rethink of traditional zoning strategies for industrial lands.
\end{abstract}

Key words: planning; land use; employment land; industrial land; intensification; local economy 


\section{ACKNOWLEDGEMENTS}

The emotional, professional, and financial support of my family has been the foundation of my academic career and this would not have been possible without them.

While at Ryerson, I am grateful for having been fortunate enough to work with a diverse group of intelligent and ambitious classmates who, I'm certain, will push the boundaries of the Planning profession during their careers.

Finally, I would like to acknowledge the dedication and professionalism of the faculty members of the School of Urban and Regional Planning who have inspired me to pursue this dynamic and innovative profession. I want to specifically thank Professor Steven Webber for his invaluable contributions to my research (and baseball knowledge) this past academic year, and Professor David Amborski for reviewing and refining this paper. 
Title Page

Author's Declaration

Abstract

Acknowledgements

Table of Contents

List of Tables

List of Figures

i

ii

iii

iv

$\mathrm{vi}$

vii

viii

1.0

Introduction

1

1.1 Purpose of this Research 1

1.2 Case Study Location 2

2.0

Importance of Employment Lands

4

2.1 History of Employment Lands 6

2.2 Threats to Employment Lands 8

3.0

Policy Context

3.1 Provincial Policy Statement

3.2 Growth Plan for the GGH

3.3 Region of York Official Plan

3.4 City of Markham Employment Lands Strategy

3.5 City of Markham Official Plan

4.0

Methodology

4.1 Summative Content Analysis

4.2 Research Process

5.0

Case Study: City of Markham

20

5.1 Introduction

20

5.2 Analysis of Planning Justification

24

5.3 City of Markham Response

31

5.4 Emerging Issues

32

6.0

Recommendations

40

7.0

Conclusion

45

Appendices

47

References

50 


\section{LIST OF TABLES}

Table 1: Property Taxes, by Property Class, Per $\$ 100,000$ of Assessed Property Value - York Region (Page 4)

Table 2: Growth Plan for the Greater Golden Horseshoe, Key Targets (Page 12)

Table 3: YROP Growth Forecasts, City of Markham (Page 14)

Table 4: Land Supply Requirements, Employment Uses, City of Markham (Page 15)

Table 5: Conversion Matrix Summary Table (Page 20) 


\section{LIST OF FIGURES}

Figure 1: Map of Subject Sites, City of Markham (Page 23) 


\subsection{Introduction}

Realities of the real estate market have resulted in many Southern Ontario municipalities currently experiencing pressure from landowners and developers to convert designated employment lands to non-employment uses. In responding to applications for conversion, municipal decision makers must navigate an array of recent provincial planning policy documents and consider stringent employment and population targets. This paper will analyze the content of 12 employment land conversion applications submitted to the City of Markham in 2013. The purpose of this exercise is to assess how applicants are interpreting and utilizing various layers of policy (provincial, regional, and municipal) to justify their proposals to convert employment lands. By assessing the policy interpretations embedded within the planning rationale reports associated with conversion applications, it becomes possible to assess how applicants are leveraging specific sections of policy to support their conversion proposals. This process provides the opportunity to consider the manner in which applicants, and city staff, are interpreting the overall goals of Ontario's provincial planning framework as they advance their interests.

\subsection{Purpose of this Research}

The planning framework currently in place in the Province of Ontario is heavily based on principles of smart growth including transit oriented development, intensification, and a focus on building complete communities. These principles of smart growth have been increasingly gaining traction in North American urban areas in the interest of improving quality of life and reducing environmental degradation. While the advancement of these development principles has been positive in certain cases, the literature also identifies that 
industrial lands may face significant redevelopment pressure as smart growth principles are adopted. Green Leigh and Hoelzel (2012) identify that the discourse of smart growth can have unintended consequences of stimulating the demand to convert industrial lands to residential and commercial uses. Moreover, they argue that planning policies guided by smart growth principles often do not meaningfully consider the implications for industrial lands.

This paper provides the opportunity to assess the extent of which this is the case in the context of the City of Markham. An analysis of 12 conversion applications submitted to the City provides for an on-the-ground case study of how the planning framework in Ontario, informed by smart growth principles, is leveraged by developers to support employment land conversions. The literature has, theoretically, linked smart growth principles to pressure for employment land conversion (Green Leigh and Hoelzel, 2012). This paper aims to move past theoretical assumptions to assess a case study of how, in practice, smart growth-based planning policies are interpreted to support employment land conversions.

\subsection{Case Study Location: City of Markham}

The City of Markham is a lower tier municipality located in York Region, north of the City of Toronto, east of the Town of Richmond Hill, and south of Whitchurch-Stouffville. It is currently the sixteenth largest municipality in Canada (by population size) and has grown by 74\% between 1996-2001 (Statistics Canada, 2012). The City's economy is heavily based on the high-tech and corporate office sectors, which account for $25 \%$ of the city's overall employment (City of Markham, 2013). 
Similar to many growth-intensive municipalities in North America, Markham has been experiencing significant pressure from developers and land owners to convert designated employment lands to non-employment uses. As per provincial requirements set out in the Growth Plan (2008), development applications that constitute "employment land conversions" must be submitted at the time of a "municipal comprehensive review (MCR)." Markham has been recently engaged in a MCR to bring its Official Plan in line with the intensification targets associated with Places to Grow and the Growth Plan. In conjunction with this, various land owners have submitted applications for Official Plan Amendment to convert designated employment lands to allow for increased land use flexibility on their respective sites. A total of twelve conversion applications had been submitted to city staff as of October 2013 as part of the MCR process. These 12 applications, and the planning justification articulated by their proponents, are the basis for this research.

It is important to note, in regards to this Case Study, that the analysis represents a snapshot of the original submissions and not any materials that may have been modified and/or resubmitted since January 2014. 


\subsection{The Importance of Employment Lands}

There are numerous benefits associated with employment lands cited in the literature and in policy documents. Preserving an adequate supply of employment land is seen as critical to ensuring that a municipality can remain economically competitive (Hemson Consulting, 2008). In this sense, ensuring an adequate supply of industrial and commercial land is considered an important factor in attracting potential investments. Moreover, maintaining an adequate employment land base is critical to ensuring a sufficient tax base. This is particularly relevant in Ontario as many municipalities historically structure the property tax in a way that places a significant share of the tax burden on non-residential land uses (Slack, 2002). To illustrate this, it is useful to compare the tax burden between property classes in the GTA:

\section{Table 1:}

Property Taxes Per $\$ 100,000$ of Assessed Property Value (2009)

\begin{tabular}{|l|l|l|l|}
\hline Municipality & Residential & Commercial & Industrial \\
\hline Toronto & $\$ 603$ & $\$ 1,978$ & $\$ 2,148$ \\
\hline Markham & $\$ 757$ & $\$ 914$ & $\$ 1,040$ \\
\hline Richmond Hill & $\$ 769$ & $\$ 928$ & $\$ 1,056$ \\
\hline Vaughan & $\$ 763$ & $\$ 921$ & $\$ 1048$ \\
\hline
\end{tabular}

Source: http://www.cfib-fcei.ca/cfib-documents/on0465.pdf

This data clearly demonstrates the revenue benefits of employment lands to municipalities.

While the fairness and utility of this tax burden distribution has been criticized in the literature (CFIB, 2009), this practice has continued over time and is difficult to alter. 
Difficulties in shifting this burden are rooted in practical implementation issues and political unwillingness, given that residential land users vote in municipal elections (Slack, 2002). Employment land uses, therefore, are critical sources of property tax revenue for municipalities who may lack the political will to redistribute the tax burden. This further illustrates the importance of maintaining a supply of designated employment land.

Maintaining an adequate supply of employment lands within a municipality is also seen as a critical measure towards building "complete communities." The idea of building complete communities is predicated on the notion that community residents should be able to "live, work, shop, and play" in the same general neighborhood (Growth Plan, 2008). The environmental, economic, and social benefits associated with this form of mixed-use development require the setting aside of land for a variety of diverse uses. If proactive planning and land-use designation is not implemented, there is the potential that profitdriven, risk averse developers may focus their efforts on more secure residential development projects (Canadian Urban Institute, 2013; Barer, 2011). Therefore, another perceived benefit of protecting employment land is to ensure that the municipality can foster a diverse mix of land uses.

While the benefits noted above may inspire the development of employment land protection policies, it is critical to understand that municipalities within Ontario's Greater Golden Horseshoe are required to comply with provincial policies in addition to considering their own economic needs. In this sense, municipalities are also bound to protecting employment lands by multiple layers of provincial policy. 


\subsection{History of Employment Lands in the Greater Toronto Area}

Since the post-war period, the intersection of land use policy changes and investment in infrastructure has greatly impacted the nature and location of employment lands in the Greater Toronto Area. The City of Toronto was significantly impacted by the growth of major industries in the post-war period that resulted in major commercial development in the downtown core (Canadian Urban Institute, 2013). As a result of this concentration of economic activity, the city began to experience congestion issues as workers flocked to downtown office buildings from their new homes in the suburbs. This intense and concentrated congestion galvanized the Toronto Transit Commission into investing in the creation of the City's first subway line in 1954 (Canadian Urban Institute, 2013).). The 401, 403, and 410 highways were built a decade later as reliance on automobile transportation began to increase. During this time period, the Greater Toronto Area was home to an abundance of light industrial and manufacturing land uses that required large tracts of land and access to rail transportation (Canadian Urban Institute, 2013). Moreover, the extension of the 400 series highways provided ample exposure and accessibility for new tracts of employment land (Canadian Urban Institute, 2013).

The extension of the Don Valley Parkway in 1977 (known as the 404) provided an increasing supply of accessible and highly visible employment land into the outer suburbs of the region (Canadian Urban Institute, 2013). This infrastructure expansion, combined with increased residential development in suburbs, contributed to increased demand for employment land in outer GTA suburbs. In the late 1970s, many inner Toronto suburbs increased the property tax burden on the industrial property class in an effort to generate revenue to support increased demand for services. This, combined with newly accessible industrial lands in 
outer suburbs due to the 404 expansion, resulted in industrial sites in Markham and Richmond Hill being more desirable to firms (Canadian Urban Institute, 2013). Since then, these outer suburban municipalities have come to rely on these employment land uses. In this sense, benefits are secured as an adequate base of employment land as critical to a municipality's competiveness, mostly due to the revenue generated from a large commercial and/or industrial tax base (CFIB, 2009). Moreover, the idea of promoting complete and diverse economies has been embraced by economic development agencies which has further solidified the presence of significant tracts of employment lands in these outer suburbs (City of Markham, 2013; Hemson, 2008) The combination of these factors has resulted in the outer suburbs maintaining significant tracts of employment land to the present day.

In addition to this, nearly all GTA municipalities have recently promoted policies of employment land protection as advocated for by provincial policy, therefore further acknowledging the importance of these land uses to their overall economic base. The idea of employment land protection can be traced back to early planning policies that advocated for the separation of industrial land uses from more sensitive land uses (Pendall et al, 2006). This concept manifests itself through Euclidean zoning permissions to ensure that industrial firms prosper while creating a mutually protective relationship between residential and industrial uses (Canadian Urban Institute, 2013). While the utility of this practice may be questioned, it has continued to thrive as an accepted "good planning" practice since the post-war period. 
Therefore, historical economic factors and infrastructure investments laid the foundation for employment land concentration in outer suburbs of the GTA. Moreover, the long-term existence of commercial/industrial lands results in them becoming a relied upon aspect of the tax base and municipal economy. These factors, combined with historical planning and zoning principles, necessitate employment land protection policies that attempt to ensure the maintenance of the land supply. The inherent tension and conflicts involved in protecting these employment lands are the basis for this paper.

\subsection{Current Threats to Employment Lands}

It has been well documented in the media and literature (Alamenciak, 2013; Hemson Consulting, 2008; Watson and Associates, 2011; Stanford, 2013) that many municipalities in the Greater Golden Horseshoe are experiencing pressure from developers and land owners to convert employment lands to non-employment uses. There are a variety of economic and policy-based factors contributing to this pressure for employment land conversion.

Much of the pressure to convert employment lands is attributed to simple supply and demand factors of land economics. In many GGH municipalities, land uses that generally offer increased profit streams (mainly residential and commercial), are in higher demand (City of Mississuaga, 2008). The fact that these uses are considered safer investment decisions, combined with increased market value attributed to increased demand, results in risk-averse developers as well as land owners being incentivized to attempt to convert currently designated industrial lands (Watson and Associates, 2011; Alamenciak, 2012). In addition to this, the limited supply of designated greenfields with residential permissions in 
many GGH municipalities also contributes to conversion pressure (Watson and Associates, 2011).

Moreover, the relatively large profits associated with residential uses allow developers to outbid parties who may be looking to develop land for employment uses (Stanford, 2013). This also may contribute to increased land speculation as owners and potential developers are willing to purchase and hold designated employment lands in the interest of potentially converting them in the medium to long term. This may contribute to designated employment lands remaining unused as speculators foresee future profit potential. The current policy framework requiring all applications for conversion to be considered during a municipal comprehensive review may also contribute to an increased volume of applications being received within a small timeframe. 


\subsection{Policy Context}

Land use planning in Ontario is a provincially guided process. It is the role of the province to articulate broad policy goals that upper and lower tier municipalities must adhere to. As per Section 3 of the Planning Act, all planning decisions must be "consistent with" provincial interests as outlined in the Provincial Policy Statement. The following will provide an overview of the planning policy context that the City of Markham must operate within in regards to employment lands.

\subsection{Provincial Policy Statement (2014)}

The Provincial Policy Statement (PPS) is a critical document that "sets the policy foundation for regulating the development and use of land" in Ontario (PPS, 2014). This policy document provides broad guidance for policy makers and sets the direction for which all other planning documents must adhere to (Official Plans, Secondary Plans etc.). As per the Planning Act, decisions that affect planning and land use in the province "shall be consistent with" with the PPS.

The PPS defines employment areas as:

"areas designated in an official plan for clusters of business and economic activities including, but, but not limited to, manufacturing, warehousing, offices, and associated retail and ancillary facilities." (PPS, 2014:30).

In regards to this, the PPS specifically promotes the accommodation of an appropriate range and mix of employment uses and activities (1.1.1). Section 1.3 - Employment Areas, advises planning authorities to provide for a mix of employment uses to create the 
opportunity for a "diversified economic base, including maintaining a range of suitable sites for employment uses." Providing for a mix of employment uses is also supported as a means to reduce emissions and allow for reduced congestion and commute times (1.8.1). The PPS also advises municipalities to consider and plan for the protection and preservation of employment areas for current and future uses, while acknowledging the needs of existing and future businesses. Policy 1.2.6 of the PPS identifies the need to "enhance the protection for major industries and facilities from new and incompatible uses that can impact their ability to continue."

Section 1.3.2.2 is particularly noteworthy for the purposes of this paper, as it outlines the process that planning authorities must go through when considering applications to convert employment lands to non-employment uses. It affirms that conversions may only be permitted through a municipal comprehensive review. A comprehensive review is initiated by a planning authority and involves and in-depth review of population and growth projections in the interest of assessing how best to accommodate future growth and demand while accounting for provincial interests (PPS, 2014). In this sense, the PPS affirms that conversions to non-employment uses must be carefully considered and cannot be permitted on a piecemeal basis. This section of the PPS informs the process that Markham is going through in regards to its review of conversion applications, which is the focus of this paper.

\subsection{Places to Grow: Growth Plan for the Greater Golden Horseshoe (2006)} The Growth Plan for the Greater Golden Horseshoe (GPGGH) is a document created under the Province's Places to Grow Act, 2005. The plan essentially provides a framework for 
managing population and economic growth through 2041. The Plan calls for proactive planning that provides for the opportunity to build "compact, vibrant, and complete communities" (1.2.2), in the interest of curbing the negative externalities associated with urban sprawl.

In supporting this concept, a key component of the plan is the development of density and intensification targets to be met in the region through 2041. There are three key targets set out in the plan, which are summarized below:

Table 2: Growth Plan for the Greater Golden Horseshoe, Key Targets

\begin{tabular}{|l|l|}
\hline Target & Goal \\
\hline Minimum Intensification (general) & $\begin{array}{l}\text { 40\% of new residential units must be } \\
\text { located in existing built up areas }\end{array}$ \\
\hline $\begin{array}{l}\text { Designated Greenfield Area Minimum } \\
\text { Density }\end{array}$ & $\begin{array}{l}\text { Future development must achieve } 50 \\
\text { jobs + people/hectare }\end{array}$ \\
\hline Urban Growth Centre Minimum Density & $\begin{array}{l}\text { Each of } 25 \text { has a specified target of } \\
150-400 \text { jobs + people/hectare }\end{array}$ \\
\hline
\end{tabular}

Source: The Neptis Foundation, 2013

A critical component of the GPGGH is the population and employment forecasts contained in Schedule 3 of the plan. Schedule 3 contains specific projections for population and employment growth for upper-tier municipalities in the GGH. The Region of York, for example, is forecasted to accommodate population growth to $1,790,000$ by 2041 and employment growth to 900,000 over the same period. The Growth Plan sets the growth forecasts for upper-tier municipalities, who then forecast more specific growth targets for the lower-tier municipalities within their jurisdiction. 
In terms of employment areas, the plan is consistent with the PPS in advocating for the preservation of employment areas and the maintenance of a mixture of employment uses. The GPGGH also builds on the requirement to consider conversions to non-employment uses only as part of a municipal comprehensive review. Section 2.2.6(5) provides decision makers and applicants with a set of tests that must be acknowledged during the conversion process. The plan states that conversions can only be permitted if it is demonstrated that:

a) There is a need for the conversion

b) The municipality will meet the employment forecasts allocated to the municipality pursuant to this Plan

c) The conversion will not adversely affect the overall viability of the employment area, and achievement of the intensification target, density target, and other policies of this plan

d) There is existing or planned infrastructure to accommodate the proposed conversion

e) The lands are not required over the long term for the employment purposes for which they are designated

f) Cross-jurisdictional issues have been considered

These requirements set out in the Plan are critical for the purposes of this paper, as they identify a lens through which decision makers and applicants must look when considering conversions to non-employment uses. The identification of these tests allows for a somewhat standardized application process that, in turn, allows for relative ease in comparisons and analysis. 


\subsection{Region of York Official Plan}

The York Region Official Plan (YROP) follows from the PPS and GPGGH and provides more specific guidance to the lower-tier municipalities within the Region. The plan identifies the need to ensure that municipalities provide a diverse range, size, and mix of employment lands to create a competitive business environment (4.1.1). Moreover, in accordance with the upper-tier forecasts set out in the GPGGH, the YROP sets out the lower tier employment and population targets for those in the Region. As per the Plan, these employment forecasts are meant to provide the basis for planning for employment lands in each municipality (4.3). The forecast for Markham is as follows:

Table 3: YROP Growth Forecasts, City of Markham

\begin{tabular}{|l|l|l|l|l|l|}
\hline Markham & 2006 & 2016 & 2021 & 2026 & 2031 \\
\hline Population & 273,000 & 337,800 & 370,300 & 398,300 & 421,600 \\
\hline $\begin{array}{l}\text { Employment } \\
\text { (jobs) }\end{array}$ & 144,800 & 200,300 & 221,500 & 231,200 & 240,000 \\
\hline
\end{tabular}

Source: YROP; Table 1

Section 4.3.16 further articulates that "development on fully serviced employment lands" must be "compact and achieve a region-wide average minimum density of 40 jobs per hectare." In relation to this, the YROP advises that opportunities for intensification must be carefully considered by local municipalities $(4.3 .17 ; 4.3 .18)$. Moreover, employment intensification and increased job density is encouraged within Regional Centres and Corridors (4.3.21). Within Markham, a Regional Centre is designated north of Avenue 7, in between Warden Avenue and Kennedy Road (YROP Map 1). The entire length of Avenue 7 running through Markham, meanwhile, is designated as a Regional Corridor. 
York Region also has a more detailed Regional Land Budget from which the forecasts, outlined above, are based (City of Markham, 2013). This document breaks down forecasted land requirements for employment uses into three categories, major office (MOE), population-related (PRE), and employment land (ELE). MOE refers to employment uses in large office buildings directed to regional centres, corridors and along transit routes, as per the GPGGH (City of Markham, 2013). PRE refers to employment that serves local populations including retail and service uses. ELE refers to manufacturing, warehousing, processing, and other more land intensive uses that require large tracts of land supported by transportation infrastructure (City of Markham, 2013). In terms of land requirements, the following chart outlines the forecasted land requirements for each type based on the regional budget through 2031 (the Region has not yet updated their forecasts to reflect 2041 projections in the Growth Plan).

Table 4: Land Supply Requirements, Employment Uses (2006-2031)

\begin{tabular}{|l|l|l|l|l|}
\hline & Jobs & $\begin{array}{l}\text { Jobs/Ha } \\
\text { (approx.) }\end{array}$ & Hectares & $\%$ \\
\hline MOE & 84,800 & 205 & 414 & 19 \\
\hline ELE & 83,000 & 60 & 1383 & 61 \\
\hline PRE & 35,600 & 75 & 462 & 20 \\
\hline Total & 202,400 & & 2259 & 100 \\
\hline
\end{tabular}

Source: City of Markham, 2013

These land supply requirements are carefully calculated and municipalities often set aside lands strictly to meet these forecasts. The result of this is that potential conversions to non- 
employment uses can significantly challenge the ability of municipalities to reach their forecasted land (and therefore, employment) requirements.

\subsection{City of Markham Employment Lands Strategy (2009)}

Markham developed an Employment Land Strategy (ELS) in 2009 as a starting point to inform the policies that would be included in the new Official Plan. The ELS recommended that all of the lands designated for employment be protected from conversion to retail and

residential uses (City of Markham, 2009). The report identified that Markham required all of its currently designated employment lands in order to meet the forecasts set out in the YROP. It also identified that Markham may experience a pending industrial land deficit that would be exacerbated by newly approved conversions (City of Markham, 2009).

\subsection{Markham Official Plan (2012)}

The new Markham Official Plan develops land use designations based directly on the employment forecasts assigned to it by the Region. As previously discussed, the YROP breaks down employment forecasts into MOE, PRE, and ELE categories. The Draft Official plan breaks down employment lands into designations based on each of these specific categories. Moreover, Markham staff have identified that the lands set aside for employment, based on Regional targets, represent the minimum land required to reach the forecasted job numbers. In this sense, any conversion of employment land would have to be made up for somewhere else in the City in order to Markham to reach the Regional forecasts, as no surplus employment land has been planned for. 


\subsection{Methodology}

\subsection{Summative Content Analysis}

This study invokes qualitative observation to deduce meaning from planning documents. Defined more specifically, this project embraces the process of content analysis to assess and evaluate the subject material. Qualitative content analysis is used in a wide range of disciples as a way to analyze text data (Hsieh and Shannon, 2005). The purpose of content analysis is, essentially, to invoke knowledge and understanding of the specific phenomenon under study (Hsieh and Shannon, 2005). Studies that utilize content analysis are often faced with a significant quantity of text data to analyze. Due to this, content analysis frequently involves a process of data coding. This process is used to clearly organize the data and identify themes and patterns within the subject text (Hsieh and Shannon, 2005). Content analysis is used in a variety of disciplines to analyze data, including in research related to land use planning. Boswell et al (2010) conducted a content analysis of thirty climate change action plans in the interest of assessing the value and consistency of greenhouse gas emission measurements. Retzlaff (2008) utilized the content analysis approach to analyze the details of various sustainable building assessment systems. Content analysis, therefore, represents a methodological approach conducive to studying the intricacies of planning-related documents.

While content analysis is the broad term referring to the process of deducing meaning from text through the identification of patterns and themes, this study utilizes a more specific methodological approach referred to as summative content analysis. Summative content analysis is unique in that it is an approach to text-data analysis that does not apply a priori 
theory to the material being studied (Hsieh and Shannon, 2005). Instead, the initial analysis of the subject text merely involves identifying the frequency of which certain words or phrases are present in the material. For the purpose of this study, certain key words were identified, as were specific policy sections. By using a summative content analysis approach, it was possible to identify the policies that were most commonly being used as justification to advance one party's interests (applicants or city staff). This methodological approach allowed for more clear organization of the text and, therefore, a more focused analysis.

\subsection{Research Process}

Based on the methodological justification above, this paper explores the details of the employment land conversion applications submitted to the City of Markham. The purpose of this exercise is to assess how applicants are interpreting and utilizing various layers of policy (provincial, regional, and municipal) to justify their proposals to convert employment lands. By assessing the policy interpretations embedded within the planning rationale reports associated with the conversion applications, it becomes possible to assess how applicants are leveraging policy to support their conversion proposals.

In order to conduct this research, publically available development application material was retrieved. These materials include Official Plan Amendment application forms, cover letters, planning rationale reports, draft site plans, and other associated documentation included as part of an employment land conversion application. The first step involved in documenting the content of these materials was the creation of a matrix outlining the characteristics of each conversion application (see next page). This process identified the basic 
characteristics of each of the subject sites, as well as the details of the proposal and a summary of the applicant's justification. The chart-style layout of this data is meant to allow for ease of comparison between applications.

The next step involved identifying the policy documents that were cited by the applicants within their planning rationale. This data was tracked in spreadsheet format that allowed for clear identification of policy sections that were more consistently cited in support of conversion proposals. Specific policies that were more frequently cited were, then, assessed in detail as they represent the most relied upon "evidence" supporting applicant's proposals. Once policy sections were identified, common themes and arguments present in the applications were categorized for ease and clarity in presenting the findings.

The final step involved comparing the proponent's justification with the responses from City of Markham Planning staff. In order to do this, staff reports and relevant public meeting minutes were gathered and analyzed. The purpose of this process was to pinpoint the discrepancies in policy interpretation between the two parties. 


\subsection{City of Markham Case Study}

\subsection{Introduction}

In order to evaluate and compare between of the conversion applications submitted to the City of Markham, it was necessary to identify a standardized set of characteristics through which they would be initially assessed. Once a set of characteristics were identified and observed, the data was recorded in table format. The purpose of this was to provide a clear and organized database of application characteristics.

Table 5: Conversion Matrix Summary Table

\begin{tabular}{|c|c|c|c|}
\hline Application & Site Location & Proposed Use & $\begin{array}{l}\text { Applicant } \\
\text { Justification }\end{array}$ \\
\hline $\begin{array}{l}1 \\
\text { OP } 10116596\end{array}$ & $\begin{array}{l}\text { Northwest corner of Woodbine } \\
\text { and Markland }\end{array}$ & $\begin{array}{l}\text { Mixed use area } \\
1.8 \mathrm{FSI} \text { total } \\
0.5 \mathrm{FSI} \text { Residential }\end{array}$ & $\begin{array}{l}\text { Should not be a conversion } \\
\text { as merely adding a } \\
\text { residential designation. } \\
\text { Employment uses to } \\
\text { remain. Mostly retail, hotel } \\
\text { jobs to be created. }\end{array}$ \\
\hline $\begin{array}{l}2 \\
\text { OP } 12132870\end{array}$ & $\begin{array}{l}\text { South of Hwy 7, west of } \\
\text { Donald Cousens Parkway }\end{array}$ & $\begin{array}{l}\text { Med- High Density } \\
\text { Residential + } \\
\text { Commercial/Retail Anchor + } \\
\text { Employment Uses }\end{array}$ & $\begin{array}{l}\text { Higher density employment } \\
\text { uses are proposed with } \\
\text { mixing of uses. Shift away } \\
\text { from business parks to } \\
\text { more sustainable and } \\
\text { marketable employment } \\
\text { space. }\end{array}$ \\
\hline $\begin{array}{l}3 \\
\text { OP } 13108173\end{array}$ & $\begin{array}{l}\text { South of } 407, \text { north of Copper } \\
\text { Creek Drive }\end{array}$ & $\begin{array}{l}\text { Banquet and Conference } \\
\text { Hall + Medium Density } \\
\text { Residential + live/work } \\
\text { units }\end{array}$ & $\begin{array}{l}\text { OP targeted uses are not } \\
\text { suitable for these lands. } \\
\text { Banquet hall jobs will still } \\
\text { be created ( } 42 \% \text { of } \\
\text { allocated employment). Lost } \\
\text { jobs will be made up for in } \\
\text { other developments in the } \\
\text { City. Subject site } \\
\text { represents small portion of } \\
\text { overall employment land. } \\
\text { Isolated location reduces } \\
\text { marketability. Close } \\
\text { residential uses render it } \\
\text { difficult to market for } \\
\text { targeted uses. }\end{array}$ \\
\hline $\begin{array}{l}4 \\
\text { OP } 13108448\end{array}$ & 14th Avenue and Middlefield & $\begin{array}{l}\text { Re-designate to Urban } \\
\text { Residential - permitting } \\
\text { housing with limited } \\
\text { complimentary ancillary } \\
\text { uses. Rezone southern } \\
\text { portion to residential for } \\
\text { mixture of ground related } \\
\text { housing types - leave } \\
\text { northern portion fronting } \\
\text { onto } 14^{\text {th }} \text { as "industrial." }\end{array}$ & $\begin{array}{l}\text { OP encourages housing in } \\
\text { already serviced and built } \\
\text { up areas. Identified need to } \\
\text { diversify housing stock is } \\
\text { addressed by the proposal. }\end{array}$ \\
\hline $\begin{array}{l}5 \\
\text { OP } 13108797\end{array}$ & John St and Greenlane & $\begin{array}{l}\text { Townhouses and mixed-use } \\
\text { low rise development along }\end{array}$ & $\begin{array}{l}\text { Residential development } \\
\text { surrounding the site has }\end{array}$ \\
\hline
\end{tabular}




\begin{tabular}{|c|c|c|c|}
\hline & & $\begin{array}{l}\text { the more major routes on } \\
\text { the boundaries of the site } \\
\text { (John St and Greenlane). }\end{array}$ & $\begin{array}{l}\text { resulted in limitations on } \\
\text { the actual industrial activity } \\
\text { that is appropriate. A } \\
\text { progression from residential } \\
\text { to mixed use is more } \\
\text { desirable. Extremely small } \\
\text { amount of employment land } \\
\text { proposed to be converted. }\end{array}$ \\
\hline $\begin{array}{l}6 \\
\text { OP } 13113480\end{array}$ & SW Corner of 404 and Hwy 7 & $\begin{array}{l}\text { New convention facility or } \\
\text { theatre + Mid/high rise } \\
\text { residential + office + hotel. } \\
\text { Increase density from } 90 \% \\
\text { to } 209 \% \text {. }\end{array}$ & $\begin{array}{l}\text { Keeps some employment } \\
\text { designations and intensifies } \\
\text { employment uses through } \\
\text { office and hotel } \\
\text { development. Mixed use } \\
\text { proposal is ideal in } \\
\text { response to demographic } \\
\text { shifts (millennials desiring } \\
\text { amenity rich spaces). } \\
\text { Transit supportive, mixed } \\
\text { use node seen as } \\
\text { highest/best use for site. }\end{array}$ \\
\hline $\begin{array}{l}7 \\
\text { OP } 13114027\end{array}$ & Warden and Elgin Mills & $\begin{array}{l}\text { Re-designate to } \\
\text { Commercial-Corridor to } \\
\text { allow for commercial + } \\
\text { residential + employment } \\
\text { mixed used. }\end{array}$ & $\begin{array}{l}\text { Proposed employment } \\
\text { targets can be hit on this } \\
\text { land while building } \\
\text { commercial + residential at } \\
\text { the same time - in the } \\
\text { interest of complete } \\
\text { communities. Designating } \\
\text { strictly for Future } \\
\text { Employment Uses is not in } \\
\text { line with provincial policies } \\
\text { of mixing uses. Best use } \\
\text { involves a more flexible } \\
\text { zoning designation. }\end{array}$ \\
\hline $\begin{array}{l}8 \\
\text { OP } 13114066\end{array}$ & $\begin{array}{l}\text { South of Elgin Mills, between } \\
404 \text { and Woodbine by-pass }\end{array}$ & $\begin{array}{l}\text { Re-designate to } \\
\text { Commercial, Community } \\
\text { Amenity - Business Area for } \\
\text { residential + employment } \\
\text { mixed use. Essentially } \\
\text { looking to expand the } \\
\text { current uses allowed by } \\
\text { applying the Commercial } \\
\text { designation. }\end{array}$ & $\begin{array}{l}\text { Existing employment } \\
\text { designation is too rigid and } \\
\text { does not allow for complete } \\
\text { communities as per } \\
\text { Provincial Policy. The } \\
\text { market is dictating flexible, } \\
\text { amenity rich employment } \\
\text { spaces, not traditional ELE. }\end{array}$ \\
\hline $\begin{array}{l}9 \\
\text { OP } 13114950\end{array}$ & $\begin{array}{l}\text { Woodbine Road and Markland } \\
\text { Street }\end{array}$ & $\begin{array}{l}\text { Re-designate from industrial } \\
\text { to residential mid, low-rise. }\end{array}$ & $\begin{array}{l}\text { To align site with } \\
\text { surrounding land use } \\
\text { context. The existing } \\
\text { permitted uses are not } \\
\text { compatible with the already } \\
\text { built development } \\
\text { surrounding the site. Loss } \\
\text { of employment could be } \\
\text { made up by intensifying } \\
\text { other employment areas } \\
\text { close by. Different housing } \\
\text { units increase stock } \\
\text { diversity in the City. }\end{array}$ \\
\hline $\begin{array}{l}10 \\
\text { OP } 13116651\end{array}$ & $\begin{array}{l}\text { North of Elgin Mills West of } \\
\text { Woodbine By-pass }\end{array}$ & $\begin{array}{l}\text { To re-designate the site to } \\
\text { urban residential and } \\
\text { commercial. Proposal } \\
\text { involves a combination of } \\
\text { single detached, street } \\
\text { townhouse, rear lane } \\
\text { townhouses, and two storey } \\
\text { mixed use office building } \\
\text { with retail at grade. }\end{array}$ & $\begin{array}{l}\text { Current Industrial } \\
\text { designation is not suitable } \\
\text { for the lands- opinion is that } \\
\text { they will never be developed } \\
\text { for industrial purposes. Site } \\
\text { not seen as marketable as } \\
\text { other sites in the city are } \\
\text { more attractive industrial } \\
\text { uses. The proposal will } \\
\text { diversify housing choices for } \\
\text { consumers in Markham. } \\
\text { Site has an Environmental } \\
\text { Protection Area (woodlot) } \\
\text { adjacent to it, which makes } \\
\text { it more conducive to }\end{array}$ \\
\hline
\end{tabular}




\begin{tabular}{|c|c|c|c|}
\hline & & & residential. \\
\hline $\begin{array}{l}11 \\
\text { OP } 13116842\end{array}$ & Woodbine and 19th Ave & $\begin{array}{l}\text { Re-designate to "Industrial" } \\
\text { to facilitate the } \\
\text { development of a cemetery. }\end{array}$ & $\begin{array}{l}\text { In line with PPS in that it } \\
\text { proposes a cemetery within } \\
\text { the urban boundary and not } \\
\text { on prime agricultural land. } \\
\text { The proposed cemetery } \\
\text { meets the needs of the } \\
\text { large Roman Catholic } \\
\text { population in Markham and } \\
\text { provides affordable burial } \\
\text { options. This location would } \\
\text { require minimal municipal } \\
\text { servicing enhancements as } \\
\text { well. }\end{array}$ \\
\hline $\begin{array}{l}12 \\
\text { OP } 13131100\end{array}$ & Highway $7 \mathrm{E}$ and South Park & $\begin{array}{l}\text { To re-designate to allow for } \\
\text { mixed use development } \\
\text { including } 2,762 \text { apartment } \\
\text { units, } 68 \text { townhouse units, } \\
11,800 \mathrm{~m} 2 \text { o retail space, } \\
7,710 \mathrm{~m} 2 \text { of office space. }\end{array}$ & $\begin{array}{l}\text { The proposal helps the City } \\
\text { meet its intensification } \\
\text { targets while providing a } \\
\text { balanced housing supply. } \\
\text { The site location renders it } \\
\text { at a competitive } \\
\text { disadvantage as it is } \\
\text { separated from local ELE } \\
\text { node. Loss in employment } \\
\text { here can be made up for on } \\
\text { other future sites. }\end{array}$ \\
\hline
\end{tabular}

The subject sites of each application vary significantly in size, ranging from 1 to 50 hectares. Seven of the twelve subject sites are currently vacant, six of which are greenfield sites. Other existing uses include one farm site, one site with a single family dwelling (essentially greenfield), and another currently being used for low rise offices. In terms of proposed uses, 11 of the 12 applications are calling for the inclusion of residential uses (among others) on the subject sites. The only application not in support of future residential land uses is in regards to a cemetery proposed by the Catholic Archdiocese. The geographic distribution of the subject sites is illustrated on the following page. As the map illustrates, 8 of the 12 sites are located in close proximity to at least one of Avenue 7, Highway 404, or Highway 407. Two of the applications are located within the City's designated Urban Expansion Area, while the remaining two lie in close proximity to $14^{\text {th }}$ Avenue. In terms of neighborhood context, 8 of the 12 subject sites are located in close proximity to existing residential developments. Of the sites not abutting residential developments, 2 are located in the future urban expansion area while the other lies in an area currently developed with commercial and light industrial uses off of Avenue 7. 


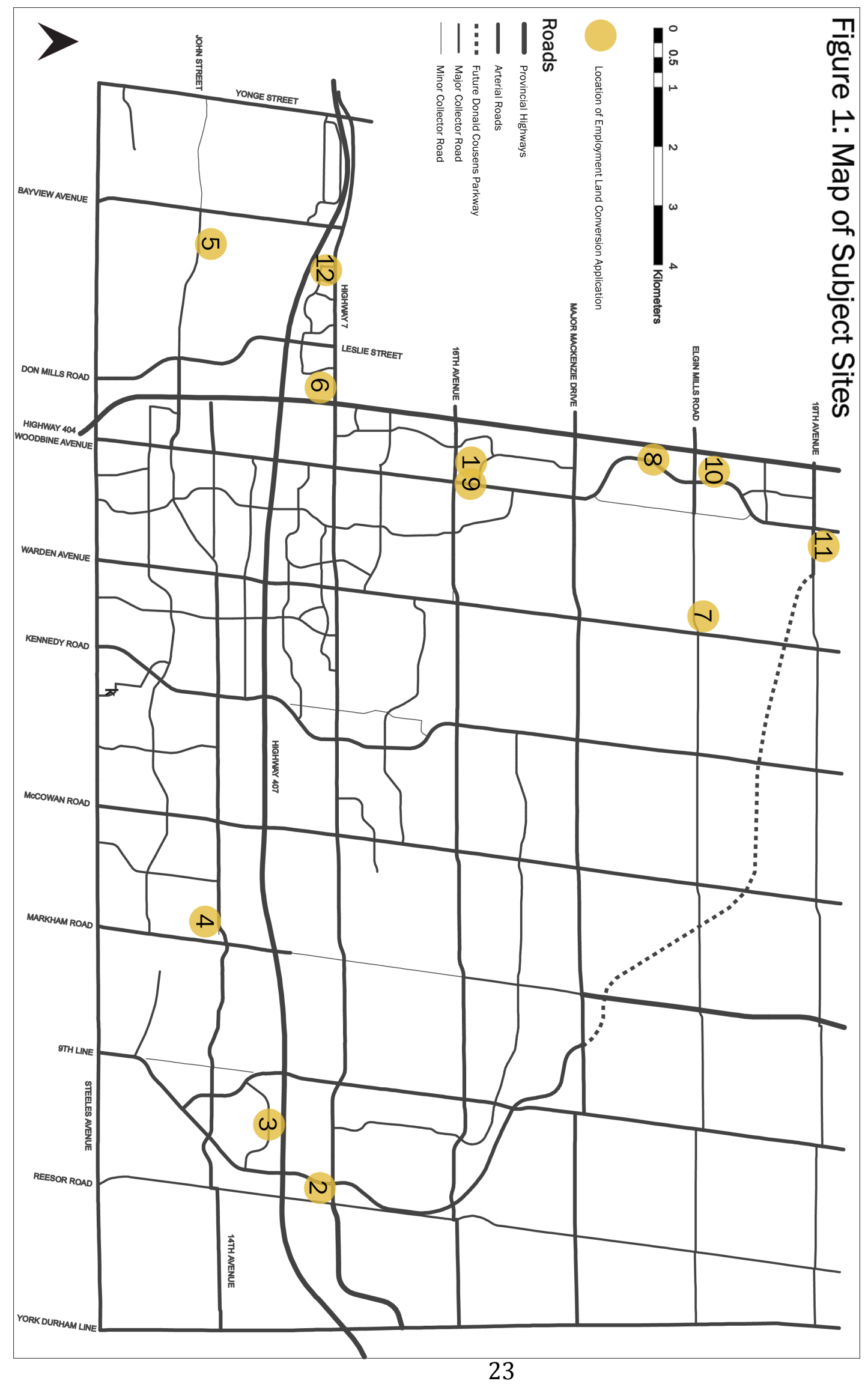




\subsection{Analysis of Planning Justification for Conversions}

The following will provide an overview of the content of the planning rationale reports submitted in support of the employment land conversion applications. The section has been divided up into subsections based on common justifications acknowledged between applications. Within these subsections, policy sections referred to in the justification reports are also identified.

\section{“Intensification"}

Residential and employment intensification is a common component of the justification reports for many of the applications. Many applicants site Section 2.2.2 of the Growth Plan, which calls for intensification in existing built-up areas. In this sense, many applicants capitalize on the location of their site to promote the need for intensification. As depicted in Figure 1, a significant amount of the sites are located along major transportation routes. Applicants recognize sites along "intensification corridors" like Avenue 7 are identified as ideal for both residential and employment intensification. These applicants also cite the YROP and the focus on intensifying "Regional Corridors" such as Avenue 7 (Bousfields, 2012).

Moreover, sites that are located within 500m of a "major transit area," as set out in the Growth Plan, are identified as being prime sites for intensification. Applicants, in this regard, cite Growth Plan policies (2.2.5) that call for intensification on these lands while promoting residential, office, institutional, commercial (Bousfields, 2012). Applicants also highlight that Section 2.2.5 of the Growth Plan does not mention ELE land uses as those promoted within “major transit station area” (Bousfields, 2012). 
Other applicants encourage intensification in the interest of contributing to the residential growth targets for Markham set out by the Region (Malone Given Parsons, 2012). Applicants specifically note that Markham's New Official Plan sets an aggressive intensification target in that $60 \%$ of new residential development is targeted towards already built-up areas (Malone Given Parsons, 2012). This aggressive intensification target is cited to justify proposals that involve the integration of residential uses on their sites (RJ Forhan and Associates, 2013; Bousfields, 2012).

Finally, applicants focus on the need to diversify the built form of Markham's housing stock as a justification for their conversion and introduction of residential uses (Gagnon and Law, 2013; Malone Given Parsons, 2013). In support of this, applicants cite Section 2.13 of the Markham Official Plan that calls for a diverse housing stock. These applications predominately point to the need to build ground-related housing in the City and in the Region. Some applicants justify this claim by referencing a housing supply and demand analysis conducted by the Region in 2012, which identified ground-related stock as being in a 5-6 year shortfall (York Region, 2012).

\section{“Encouraging Mixed-Use Nodes and Complete Communities"}

A number of the applicants justify their position as they claim the existing Official Plan designation does not allow for the creation of mixed use-nodes and the development of "complete communities" as promoted in provincial policy. Many applicants specifically cite planning ideology of separating employment areas from community areas, and how this practice may hinder the ability to develop land in conformance with provincial policy (RJ 
Forhan and Associates, 2012). Applicants claim that existing ELE designations often encourage the creation of mono-functional office and industrial parks which represent a clear contrast to the complete community ideal (RJ Forhan and Associates, 2012).

Applicants often explicitly claim that an Official Plan Amendment is necessary in the interest of developing "complete communities" on the subject sites (Bousfields, 2012). Due to the proximity to residential neighborhoods for many of the sites, applicants argue that land uses which allow for walkable, transit-oriented design and functionality are more applicable than traditional ELE uses (Bousfields, 2012; Malone Given Parsons, 2012). Intensification is also promoted in this regard, as it is argued it would allow for increased employment density and thus a greater balance of land uses within the neighborhood (Bousfields, 2012). Applicants also cite changing demographic characteristics of the population in support of their applications to develop complete, mixed use communities. The increasing demand for living space within dynamic multi-functional nodes is seen as a defining characteristic of the "millennial" generation that needs to be accounted for (Urban Strategies, 2012). In support of this, Sections 2.2.2.1 of the Markham Official Plan are cited which encourage development of complete communities. One application involves maintaining the as-of-right employment uses on site and merely adding a residential use provision (Bousfields, 2009). Again, the applicant promotes this idea as it provides the opportunity to develop a more complete community with a mix of uses.

Applicants also promote their proposed amendments as contributing to complete communities through transit supportive neighborhood design and built form. For example, one applicant's proposed uses include townhouses and live-work units on the designated 
employment lands, which they claim would render the site increasingly transit supportive (Malone Given Parsons, 2012).

\section{“Responding to Market Conditions"}

Many applicants justify their proposals in that they claim to not be necessarily removing employment land from Markham's supply, but rather merely changing the nature of the employment that will occur on the site. Many of these applications are looking to increase the diversity of employment uses permitted on site while, in many cases, integrating residential uses at the same time.

Applicants, in this sense, appear to be promoting employment uses based on what they believe would best serve the current market. Uses that are cited as more relevant to the existing market include flex space, concentrated office space, and live-work units (Bousfields, 2012; Malone Given Parsons, 2012). Applicants claim that as-of-right permissions are too restrictive and do not allow for the type of employment most relevant to the context of the site (RJ Forhan and Associates, 2012). Applicants cite criticisms within the literature condemning the negative externalities associated with uni-functional suburban business parks such as congestion, long-commute times, reduced productivity, and environmental harm (RJ Forhan and Associates, 2012).

A critical component of this position being put forward by applicants is that they argue that the employment function of the site is not being compromised. They assert this claim as the uses they put forth still involve employment uses however in a different sector than targeted by the existing designation (RJ Forhan and Associates, 2013; Bousfields, 2012; Malone 
Given Parsons, 2013; KLM Planning, 2010). This is an important distinction as the existence of some form of employment allows applicants to claim that provincially forecasted employment targets can still be met. In this case, applicants are able to claim that they are not compromising the employment targets set out in the Growth Plan that simply set out general numbers forecasting population and jobs. Meeting job targets as laid out in the York Region Official Plan, however, involves considering forecasts for each specific employment type (PRE, MOE, ELE).

The issue that this brings forth, however, is whether the nature of the jobs themselves are of issue to planning authorities (i.e. industrial vs. major office vs. population-related). The fact that Regional Policy breaks up employment lands into three categories implies that it is of concern, however it is clear that conversion proponents tend to view the targets as merely related to employment, in general. This issue will be further explored later in this document.

\section{“Stimulating Unmarketable, Stagnant Employment Land"}

Related to the issues identified above, another common justification put forth by applicants is the need to capitalize on under-utilized, unmarketable employment lands. Proponents often point to the fact that many of these lands have remained vacant for long periods of time and, therefore, represent underutilized economic assets (Gagnon and Law, 2013).

Applicants justify these claims based on various factors associated with the context of their specific site. Firstly, some proponents claim that the proximity of threatening land uses to the subject site has rendered it both unpractical and unmarketable for ELE uses. In most cases, applicants cite adjacent residential neighborhoods as contributing to the stagnation 
of the site as ELE employment land (Malone Given Parsons, 2013). In most of these cases, residential developments have been built in the area surrounding the subject sites.

Proponents, in these cases, cite the small size of their subject site relative to the residential neighborhoods as a reason for the stagnation of the land for ELE uses (Gagnon and Law, 2013; Bousfields, 2009; KLM Planning, 2013). The existence of residential neighborhoods renders the overall neighborhood character as not conducive to ELE land uses, according to proponents.

Certain applicants also cite the small size of their site relative to larger employment clusters within the region as a contributing factor to the long-term vacant condition of the land (Malone Given Parsons, 2013; Gagnon and Law, 2013; Bousfields, 2009). The combination of limited site size and isolation from other employment land clusters in the region are put forth as factors limiting the demand for the sites as ELE lands (Gagnon and Law, 2013; Malone Given Parsons, 2013).

Furthermore, some applicants cite the significant distance of their site from existing and/or planned high order transit as a factor limiting the demand for the subject site, as is (Malone Given Parsons, 2013). This point somewhat conflicts with other applicants who have sites on lands that are served by existing/planned high order transit. These applicants, as discussed above, claim that transit supportive sites are not conducive to ELE uses as these uses do not contribute to complete communities as identified in Provincial Policy (which is supported by the fact industrial and warehousing uses are not identified in the GPGGH as applicable uses in Major Transit Station Areas) (Bousfields, 2012). This represents an interesting dynamic at play regarding the fate of ELE lands in the eyes of owners and 
developers. As is clear in these examples, ELE lands can be justified as needing conversion either because of a lack of high order transit, or because there is essentially too much high order transit. In this sense, developers are perhaps speaking to the potential market reality that ELE lands require distinct contextual characteristics in order to thrive. This idea will be explored later in this paper.

Finally, two applications being put forth lie within Markham's Urban Expansion area and, therefore, are not expected to experience development in the near term. Applicants, in these cases, argue that the inflexible and often single-use permissions are not in line with Provincial policies of compact development and complete communities (RJ Forhan and Associates, 2013). In the examples noted above, many applicants were able to cite incompatibility with surrounding uses and difficulty in marketing and selling the land for ELE uses as reasons for conversion. In these cases, however, applicants are requesting conversion in areas that cannot possibly have experienced these conditions, yet. It is important to note this distinction as the applications within the urban expansion area could fundamentally alter the way that Markham's economy grows in the future.

\section{“Employment Land Intensification as Compensation"}

One of the tests that must be addressed, as per the GPGGH, when applying for a conversion is to illustrate how the municipality will be able to reach employment forecasts if the proposal is approved. In regards to this, many applicants are of the opinion that the loss of employment associated with their proposal will be easily made up in other locations within Markham, or through employment land intensification. 
Firstly, certain applicants cite other potential developments within the City as accounting for the jobs lost through the conversion of the subject sites. Various applicants cite the pending redevelopment of the Buttonville airport site as a location where any losses in employment as a result of their conversions can be made up (Gagnon and Law, 2013; Malone Given Parsons, 2013; RJ Forhan and Associates, 2013). In this sense, applicants are diverting the employment responsibility meant for their sites to other areas of Markham, where they see it is more likely and relevant for employment density to occur.

\subsection{City of Markham Response}

In May 2013, planning staff submitted a report to the Development Services Committee outlining their opinion and recommended council direction regarding the 12 conversion applications. In the report, planning staff recommended to Council that 11 of the 12 applications be denied.

Staff provided a variety of justifications for the recommendation to deny within the report. Firstly they affirm that need had not been established by the applicants. Staff identified that Markham does not need the added residential units proposed to help reach intensification targets or to diversify housing stock. They affirm that land budgets have been established which will accommodate population growth and that the designated urban expansion area can serve as the location to ensure a diverse housing stock (City of Markham, 2013:19). This, combined with the fact that the existing designated employment lands represent the minimum required to meet YROP targets, contributes to the denial recommendation. 
Staff were also of the opinion that applicants had not provided enough evidence to ensure that the broader employment areas would not be negatively impacted by the conversions and additions of residential uses. Staff identified that introducing non-employment uses could raise land values and make the broader area too expensive for existing, land-intensive uses (City of Markham, 2013). It could not be established, in the view of staff, that the conversions would not impact the surrounding area in uncertain ways.

In response to proponents claiming that the context of their site restricts demand for designated employment uses, City staff articulated that locations along major transportation routes (Hwy $7,407,404$ ) have continually thrived as employment areas and that they are keen on maintaining these lands for employment uses. Moreover, staff identifies that all of the land is necessary, as is, to ensure that Regional employment forecasts can be met, especially for ELE lands. Staff also acknowledged that market changes will be considered during the 5-year comprehensive review process, if necessary. Essentially, staff were of the opinion that the conversion requests, considered together, would represent a significant loss of vacant, designated employment lands. This would, moreover, significantly limit Markham's ability to meet its employment forecasts set it out in YROP, especially for ELE lands.

\subsection{Emerging Issues}

Upon documenting and analyzing the planning justification reports submitted in support of employment conversion applications, certain key issues emerge that appear to be at the crux of the debate between applicants and city staff. The following section will, firstly, highlight the key issues and that have arisen through this analysis. Once these issues have 
been identified and briefly discussed, relevant literature will be referenced that can, conceivably, inform decision makers with tools and information to meaningfully address these issues.

\section{Issue 1 - Disconnected perspectives regarding employment growth policies}

Based on the assessment conducted above, it is clear that there is a disconnect regarding the interpretation of employment forecasts for the City of Markham. City staff strictly interprets the Region of York Official Plan that identifies employment targets, through 2031, by employment type. In this sense, they have concerns regarding the loss of ELE lands associated with the 12 conversion requests submitted as part of the municipal comprehensive review. Because they are required to allocate land based on employmenttype specific regional forecasts, they promote the idea that certain types of jobs are required to exist within the municipality.

Conversely, some of the justification reports submitted by applicants affirm that employment uses will be provided on the subject sites (in addition to residential uses, in most cases). The issue that requires them to complete an Official Plan amendment, however, is that they often propose employment uses that are of a different nature and therefore not permitted as-of-right. Many applicants claim, however, that their applications do not restrict the City's ability to reach its employment targets as they often propose employment densities equal to or greater than what is permitted as-of-right (RJ Forhan and Associates, 2013; Malone Given Parsons, 2013). The issue is that while proposals may not necessarily restrict the attainment of Markham's overall employment forecasts as set out in the GPGGH, they do 
limit the ability to reach employment-type specific forecasts as set out in the YROP. As noted by Markham Planning staff, the proposals would significantly limit the City's ability to reach ELE targets set out in the YROP (City of Markham, 2013).

This difference of perspective between stakeholders has implications for the future structure of Markham's economy. Markham staff highlights the need to maintain a variety of uniquely designated employment lands to ensure a vibrant and diverse economy (City of Markham, 2013). Conversion proponents, however, highlight changing market forces and Provincial policies to further their position that certain employment land designations (predominately ELE) are no longer viable. The contrasting perspectives of both parties are especially complex in that they are both able to reasonably cite policy documents that advance their position. General employment targets allow proponents to promote overall job growth while industry-specific regional targets allow municipalities to defend conversions.

The lack of clarity embedded within levels of policy becomes further complicated upon assessing decisions made at the Ontario Municipal Board. In regards to employment forecasts, City planning staff can rely on Section 2.2.6.1 of the Growth Plan that encourages municipalities to provide an "adequate supply of lands providing locations for a variety of appropriate employment uses...to accommodate growth forecasts." Policies like this, along with regional employment forecasts identifying land requirements by sector type, imply a desire to ensure industrial diversity through land use planning. Moreover, these policies infer that there is utility in considering and managing the nature of employment growth through land use planning tools. 
Decisions at the Ontario Municipal Board, however, have explicitly stated that the nature of the employment should not be considered as part of the decision-making process regarding development applications on designated employment lands. In the 2006 case, St. Johns McNicoll Centre v. City of Toronto (2006), the Board's decision clearly discourages the need to consider the nature of employment as part of land use planning decisions. The case was being heard in regards to a Zoning By-law Amendment application involving the re-zoning of designated employment lands to permit a mixed use development consisting of seniors housing and a variety community facilities (Ontario Municipal Board, 2007).

One of the key issues regarding this case was whether or not the application represented an employment land conversion. The Board was of the opinion that the proposal did not constitute a conversion, due to the fact that there would be over 200 jobs created on the site for doctors, nurses, maintenance staff, and other service workers associated with the development (Ontario Municipal Board, 2007). Moreover, the Board member also explicitly identified that, as a matter of public policy, the nature and value of employment types are not to be judged (Ontario Municipal Board, 2007). In regards to this specific case, the Board member identified that the predominately service-sector jobs to be created as a result of this development should, in no way, be considered less valuable than the manufacturing and office jobs predominant in the surrounding area (Ontario Municipal Board, 2007). Therefore, the Board was of the opinion that even though the proposal changed the nature of the employment designated for the subject site, the proposal still did not warrant being considered a conversion merely because there were still jobs to be created on site. 
In another case, SmartCentres and Toronto Film Studios v. City of Toronto (2009), similar points were emphasized regarding the idea of attributing value to certain types of employment. This case was being heard in regards to an Official Plan amendment application seeking to rezone lands from the "Restricted Industrial Area" designation to allow for a retail development (Ontario Municipal Board, 2009). In this case, the City was of the opinion that they needed to protect the employment lands by restricting the potential for "retail infiltration" into the area (Ontario Municipal Board, 2009). The Board members, however, identified that there is no need to assign differing value and importance to jobs of a specific nature. The Board member identified that, based on the testimony of numerous experts, "retail jobs are recognized as economic development and as jobs counting toward the fulfillment of employment targets mandated by provincial policy" (Ontario Municipal Board, 2009). Throughout the hearing, the Board member was explicit in articulating the fact that even though the jobs being created (retail) did not represent those originally allocated for these lands (manufacturing), it still must be acknowledged that the proposed retail jobs "absolutely count towards achieving employment targets mandated in provincial policy" (Ontario Municipal Board, 2009).

The perspectives put forth by the Ontario Municipal Board in these two cases further confounds the issue facing decision makers and practitioners regarding how to interpret the intent of employment forecasts mandated in provincial and regional policy documents. The interpretations provided by Ontario Municipal Board members outlined above coincides with the perspectives put forth by conversion applicants in Markham. Both of these parties see employment targets as referring to jobs in general, assuming that public policy should not rank the value of specific job types. City staff, however, interpret employment land use 
policy as critical in ensuring a diverse set of industries are able to thrive by maintain a supply of industry specific designated lands (City of Markham, 2013). Both perspectives essentially put forth somewhat conflicting perspectives on how to manage and regulate the local economy. In this sense, it is useful to draw on economic literature to assess the theoretical merits of each position.

Tran (2011) conducted research on the relationship between industrial diversity and the effect that this has on short and long term economic growth. Industrial diversity is defined as the "variety of economic activities that reflect difference in economic structure" (Tran, 2011: 1). His analysis, conducted at the State level in the United States, found that promotion of employment and capital growth, in general, is a wise goal for short-term economic prosperity. Conversely, promoting industrial diversity is seen as beneficial for long-term economic growth and stability (Tran, 2011: 11). These conclusions echo the work of Wagner and Deller (1998) who also argue that short-term economic policy should focus on growth of employment in general while sound long-term economic policy should accentuate diversity. They argue that short-term economic policy for a locality should involve targeting high growth industries in order to ensure capital growth (Tran, 2011). Long-term economic goals, however, should be on ensuring stability through industrial diversity. Tran (2011) outlines that industrial diversity is beneficial in reducing local government exposure to broader economic trends or events. Industrial diversity, in this sense, is seen as a hedge against unforeseen periodic economic downturns within specialized industries (Tran, 2011). 
Economic theory, therefore, would suggest that there is value in both attending to the needs of current market forces and high growth sectors while pursuing industrial diversity over the long term. This implies, therefore, that neither the conversion proponents nor planning staff are taking a theoretically flawed position. The contrasting positions may simply reflect differences in priorities as developers are inclined to seek short to medium term profits while planning staff are more sensitive to the long-term viability of the local economy. The issue remains, however, that there is a fundamental difference in the way that the two parties interpret the intent of the provincial and regional employment forecasts. Planning staff focus on the industry specific targets set out in the YROP, while applicants justify conversions based general, overall job targets. The lack of clarity and consistency between various layers of policy potentially allows for these divergent interpretations to exist.

\section{Issue 2 - Questioning the utility of protecting stagnant, unmarketable employment lands}

Many of the conversion proponents in Markham cite the inflexibility of land use permissions and the incompatibility of the surrounding neighborhood as contributing to the stagnation of the subject employment lands. Many applicants provide these reasons, among others, to argue that their subject site is no longer conducive to the current designations. Essentially, proponents are claiming that the as-of-right designations do not reflect current market conditions.

The inflexible nature of employment land policies has been documented in the literature outside of the specific context of this paper. Members of the development community in the 
region have gone on record to criticize the perceived "one size fits all" nature of employment land policy (Janzen, 2012). In this sense, they are concerned with the fact that employment land protection, in their view, is too much of a top-down, "one size fits all" policy for municipalities in the region (Janzen, 2012). The holistic nature of the policy, to them, can work to ignore the complexities inherent in local economies (Janzen, 2012). The nature of this critique is similar to that of the conversion proponents in Markham, as inflexibility and a lack of connection to market trends are consistently cited.

The perceived rigid and unaccommodating nature of employment land policies has also been criticized based on the requirements of the conversion process. As per section 1.3.2 of the PPS, conversion applications may only be submitted during a municipal comprehensive review. These reviews, however, are only conducted every 5 years. Developers have criticized this requirement as it can potentially result in missed opportunities due to rapid changes in market conditions and the potential to capitalize on rapidly growing industries (Janzen, 2012). Again this critique is akin to the observations of the Markham case study, as proponents were concerned that there was demand to be met outside of the existing as-of-right use permissions.

To summarize, this issue involve landowners who are concerned with the maximizing the value of their lands and City staff who are concerned with losing their supply of designated employment lands through conversions. The following "recommendations" section will explore tools that could, potentially, cater to both of these interests. 


\subsection{Recommendations}

\section{1) Coordinate Consistency Between Layers of Policy Regarding Employment}

\section{Lands}

The previous discussion highlights how the content of different policy documents creates the potential for conflicting interpretations to emerge among stakeholders. While the Growth Plan acknowledges the need to foster an industrially diverse and competitive economy, Ontario Municipal Board decisions tend to disregard the extent to which decision makers can consider the nature of employment within land use decisions. City staff, however, articulate the perception that they are required to adhere to regional forecasts that outline employment forecasts by industry type (City of Markham, 2013).

There lies an opportunity, therefore, to attempt to reduce these contrasting interpretations of provincial and regional policy. Based on the evidence provided, it appears as though practitioners dispute the intent of employment targets. While it appears as though, to planning staff, these targets are in place to ensure industrial diversity, the OMB explicitly disregards the nature of employment in land use decisions. This represents inefficiency in land-use policy that fosters contentious and ambiguous debates regarding the employment land conversion process. In order to reduce conflicting interpretations of policy, it may be useful to consistently articulate the goals of employment land forecasts throughout policy documents at various levels of government. 
As articulated in planning literature and in the Ontario Professional Planners Institute's Code of Practice, planners are responsible to the public interest (OPPI, 2014). Part of this responsibility involves structuring meaningful debate, facilitating communication, and fostering understanding (OPPI, 2014). As illustrated by this case study, certain employment land policies do not appear to be in the public interest as their interpretation leads to confusion among practitioners attempting to make informed decisions.

\section{2.) Explore Revised Zoning Strategies for ELE Lands}

As noted above, conversion proponents in Markham consistently cite neighborhood incompatibility and lack of demand as factors contributing to the stagnation of their site. Addressing dated and ineffective zoning by-law permissions is a strategy that is commonly used for attending to land-use issues. An example of this is the City of Toronto's Tower Renewal Initiative that involved reassessing the zoning requirements of post-war apartment neighborhoods to achieve more dynamic, complete communities (CUGR, 2012). In the same way that a reassessment of zoning procedures can benefit derelict residential neighborhoods, it may be possible to do the same for industrial areas.

As discussed above, it is also clear that there is merit in both accommodating the constantly changing needs of high growth industries and attempting to maintain industrial diversity by strictly protecting lands based on industry type. In this sense, new approaches to zoning could be leveraged in certain areas identified as ideal for accommodating the needs of new, high growth industries. At the time same, however, traditional ELE lands must be protected 
and the value of this type of employment must be explicitly stated throughout layers of policy.

In terms of new approaches to zoning, "performance zoning” may potentially allow for both the accommodation of high growth sectors as well as maintenance of industrial diversity. Performance zoning represents an alternative to traditional Euclidean zoning for industrial sites. The approach is being used in numerous municipalities in the United States as a means to offer increased flexibility on industrial lands for owners while ensuring that neighborhood compatibility is maintained (RRPDC, 2001).

Performance zoning seeks to respond to critiques of Euclidean zoning and restrictive "permitted use lists," which often do not offer the opportunity to accommodate the evolution of existing industries and the development of entirely new ones (RRPDC, 2001). Instead of providing a list of permitted uses, performance zoning codes involve permitting land uses based on "site and/or activity standards" (RRPDC, 2001). Site standards involve regulating developments based on criteria related to their appearance. These can include floor area ratios, building setbacks, landscaping requirements, and height limitations, among others (RRPDC, 2001).

The idea of focusing on standards of built form as opposed to rigid permitted use criteria has been successfully implemented in the City of Toronto. This approach, also referred to as "form-based" zoning, was invoked as part of the "Kings Regeneration Initiative" in downtown Toronto in the mid 1990s (CMHC, 2013). In this case, it was used to encourage development by opening up use permissions in the stagnant "brick and bream" district in 
the southern portion of the City and was considered extremely successful in doing so (CMHC, 2013).

A focus on "activity standards" involves regulating and permitting land uses based on the outputs of the industrial use. These may include noise, vibration, particle emissions, odors, and other potentially disruptive criteria (RRPDC, 2001). The purpose of activity standards is to allow new, innovative industrial uses that may not have been specifically noted on a permitted use list to be permitted as-of-right as long as established standards are met (RRPDC, 2001).

As discussed earlier in this paper, planning for employment uses has historically involved the conscious separation of industrial uses from community areas (Canadian Urban Institute, 2013). An issue with this, however, is that these ideas become complicated within a smart-growth policy context that involves intensification and the encouragement of mixeduse nodes (Green Leigh and Hoelzel, 2012). The implementation of performance zoning is identified as a way to potentially reduce the historical perception of the incompatibility of industrial and residential uses (Ottensmann, 2005). This is achieved as rigid "permitted use" lists are replaced with more industry-flexible performance standards. Moreover, it provides landowner's with increased flexibility to gain value from their land without simply converting to non-employment uses. This can be achieved as performance zoning creates the potential to open up the demand for particular pieces of land to industries who may not be currently permitted based on Euclidean use lists (RRPDC, 2001). A limitation of this process, however, is that it does not necessarily guarantee that the subject lands will instantly become marketable. It does, however, offer the potential to vastly increase the 
number of prospective users of the land and, therefore, increase the viability of the site as employment land and, perhaps, reducing desire for conversion. 


\subsection{Conclusion}

This research has used a case study of the City of Markham to explore the intersection, in practice, between smart growth policies and employment land protection. The case study illustrated that applicants draw on numerous concepts of smart growth policy to justify their conversion proposals. Moreover, it has established that conflicting perspectives exist regarding the intent of provincial employment forecasts as well as the general viability of the subject sites for ELE purposes.

The strategies identified in the final section offer ideas towards reconciling the conflicting perspectives of the various stakeholders. Consistency between policy documents may work to reduce the potential for inconsistent interpretations while exploring more flexible approaches to zoning may result in industrial lands being more marketable for owners. These recommendations, while not fully developed for use in practice, offer insight into the addressing the problems identified through the case study analysis.

In addition to these observations at the micro level, this research highlights broader issues related to land use planning for employment. Specifically, it emphasizes a need for practitioners and academics to consider the role of planning in forecasting the nature of employment growth within municipalities. As highlighted in this paper, there is debate between practitioners regarding the role of planning in this regard. Developers state that market forces should be the catalyst in predicting the nature of employment growth, while city planners adhere to policies that advocate for proactive planning in support of industrial diversity. The Ontario Municipal Board, based on the two cases identified in this paper, 
concludes that assigning value to particular jobs is out of the scope of planning decisions.

This issue remains complex and is worthy of further exploration. 
Appendix A: Employment Land Conversion Matrix

\begin{tabular}{|c|c|c|c|c|c|c|c|c|}
\hline Application & $\begin{array}{l}\text { Site } \\
\text { Location }\end{array}$ & $\begin{array}{l}\text { Site } \\
\text { Size }\end{array}$ & Access & $\begin{array}{l}\text { Current OP } \\
\text { Designation }\end{array}$ & $\begin{array}{l}\text { Existing } \\
\text { Use }\end{array}$ & $\begin{array}{l}\text { Proposed } \\
\text { Use }\end{array}$ & $\begin{array}{l}\text { Applicant } \\
\text { Justification }\end{array}$ & $\begin{array}{l}\text { Surrounding } \\
\text { Context }\end{array}$ \\
\hline $\begin{array}{l}\text { (1) } \\
\text { OP } 10 \\
116596\end{array}$ & $\begin{array}{l}\text { Northwest } \\
\text { corner of } \\
\text { Woodbine } \\
\text { and } \\
\text { Markland }\end{array}$ & $\begin{array}{l}4.64 \\
\text { ha }\end{array}$ & $\begin{array}{l}\text { Regional } \\
\text { Road + } \\
\text { Municipal } \\
\text { Road }\end{array}$ & $\begin{array}{l}\text { Business } \\
\text { Corridor Area }\end{array}$ & Vacant & $\begin{array}{l}\text { Mixed use } \\
\text { center } \\
1.8 \mathrm{FSI} \text { total } \\
0.5 \mathrm{FSI} \\
\text { Residential }\end{array}$ & $\begin{array}{l}\text { Should not be a } \\
\text { conversion - } \\
\text { merely adding a } \\
\text { residential } \\
\text { designation. } \\
\text { Employment } \\
\text { uses to remain } \\
\text { as retail, hotel } \\
\text { jobs to be } \\
\text { created. }\end{array}$ & $\begin{array}{l}\text { Low-density } \\
\text { residential } \\
\text { community to } \\
\text { the north. }\end{array}$ \\
\hline $\begin{array}{l}(2) \\
\text { OP } 12 \\
132870\end{array}$ & $\begin{array}{l}\text { South of } \\
\text { Hwy } 7, \\
\text { west of } \\
\text { Donald } \\
\text { Cousens } \\
\text { Parkway }\end{array}$ & $\begin{array}{l}50 \\
\text { ha }\end{array}$ & $\begin{array}{l}\text { Provincial } \\
\text { Highway + } \\
\text { Municipal } \\
\text { Road }\end{array}$ & $\begin{array}{l}\text { Business Park } \\
\text { Area and } \\
\text { Avenue } 7 \text { - } \\
\text { Business Park } \\
\text { Area }\end{array}$ & $\begin{array}{l}\text { Vacant } \\
\text { greenfield }\end{array}$ & $\begin{array}{l}\text { Med- High } \\
\text { Density } \\
\text { Residential + } \\
\text { Commercial } \\
\text { Retail Anchor + } \\
\text { Employment } \\
\text { Uses }\end{array}$ & $\begin{array}{l}\text { Higher density } \\
\text { employment } \\
\text { uses + mixed use } \\
\text { node. Shift away } \\
\text { from business } \\
\text { parks to more } \\
\text { sustainable and } \\
\text { marketable } \\
\text { employment } \\
\text { space. }\end{array}$ & $\begin{array}{l}\text { Immediately } \\
\text { surrounded by } \\
\text { greenfields with } \\
\text { single family } \\
\text { neighborhoods } \\
\text { to the north } \\
\text { and west. Part } \\
\text { of a larger tract } \\
\text { of designated } \\
\text { employment } \\
\text { lands that abut } \\
\text { Donald } \\
\text { Cousens } \\
\text { Parkway and } \\
\text { Highway } 407 \text {. }\end{array}$ \\
\hline $\begin{array}{l}(3) \\
\text { OP } 13 \\
108173\end{array}$ & $\begin{array}{l}\text { South of } \\
407, \text { north } \\
\text { of Copper } \\
\text { Creek } \\
\text { Drive }\end{array}$ & $\begin{array}{l}10.6 \\
\text { ha }\end{array}$ & $\begin{array}{l}\text { Municipal } \\
\text { Road }\end{array}$ & $\begin{array}{l}\text { Industrial - } \\
\text { Business Park } \\
\text { Area }\end{array}$ & $\begin{array}{l}\text { Vacant } \\
\text { greenfield }\end{array}$ & $\begin{array}{l}\text { Banquet and } \\
\text { Conference } \\
\text { Hall + Medium } \\
\text { Density } \\
\text { Residential + } \\
\text { live/work units }\end{array}$ & $\begin{array}{l}\text { OP targeted uses } \\
\text { are not suitable } \\
\text { for these lands. } \\
\text { Banquet hall jobs } \\
\text { will still be } \\
\text { created ( } 42 \% \text { of } \\
\text { allocated } \\
\text { employment). } \\
\text { Lost jobs will be } \\
\text { made up for with } \\
\text { other } \\
\text { developments in } \\
\text { the City. Subject } \\
\text { site represents } \\
\text { small portion of } \\
\text { overall } \\
\text { employment } \\
\text { land. Isolated } \\
\text { location reduces } \\
\text { marketability. } \\
\text { Close residential } \\
\text { uses render it } \\
\text { difficult to } \\
\text { market for } \\
\text { targeted uses. }\end{array}$ & $\begin{array}{l}\text { Site lies in } \\
\text { between a } \\
\text { single-family } \\
\text { residential area } \\
\text { to the south, } \\
\text { and highway } \\
407 \text { to the } \\
\text { north. }\end{array}$ \\
\hline $\begin{array}{l}(4) \\
\text { OP } 13 \\
108448\end{array}$ & $\begin{array}{l}14^{\text {th }} \\
\text { Avenue } \\
\text { and } \\
\text { Middlefield }\end{array}$ & $\begin{array}{l}32 \\
\text { ha }\end{array}$ & $\begin{array}{l}\text { Municipal } \\
\text { Road }\end{array}$ & Industrial & $\begin{array}{l}\text { Vacant } \\
\text { greenfield }\end{array}$ & $\begin{array}{l}\text { Re-designate to } \\
\text { Urban } \\
\text { Residential - } \\
\text { permitting } \\
\text { housing with } \\
\text { limited } \\
\text { complimentary } \\
\text { ancillary uses. } \\
\text { Rezone } \\
\text { southern } \\
\text { portion to } \\
\text { residential for } \\
\text { mixture of } \\
\text { ground related } \\
\text { housing types - } \\
\text { leave northern } \\
\text { portion fronting } \\
\text { onto 14th as } \\
\text { "industrial.” }\end{array}$ & $\begin{array}{l}\text { OP encourages } \\
\text { housing in } \\
\text { already serviced } \\
\text { and built up } \\
\text { areas. Need to } \\
\text { diversify housing } \\
\text { stock is } \\
\text { addressed. }\end{array}$ & $\begin{array}{l}\text { Part of a } \\
\text { designated } \\
\text { employment } \\
\text { area that abuts } \\
\text { single family } \\
\text { residential } \\
\text { neighborhoods } \\
\text { to the south } \\
\text { and west. } \\
\text { Commercial } \\
\text { uses lie to the } \\
\text { east of the site } \\
\text { with industrial } \\
\text { lands to the } \\
\text { north. }\end{array}$ \\
\hline $\begin{array}{l}(5) \\
\text { OP } 13 \\
108797\end{array}$ & $\begin{array}{l}\text { John St } \\
\text { and } \\
\text { Greenlane }\end{array}$ & 3 ha & $\begin{array}{l}\text { Municipal } \\
\text { Road }\end{array}$ & $\begin{array}{l}\text { Industrial + } \\
\text { Business } \\
\text { Corridor }\end{array}$ & $\begin{array}{l}\text { Vacant - } \\
\text { former } \\
\text { industrial } \\
\text { site }\end{array}$ & $\begin{array}{l}\text { Townhouses } \\
\text { and mixed-use } \\
\text { low rise } \\
\text { development } \\
\text { along the more } \\
\text { major routes } \\
\text { on the } \\
\text { boundaries of } \\
\text { the site (John } \\
\text { St and } \\
\text { Greenlane). }\end{array}$ & $\begin{array}{l}\text { Residential } \\
\text { development } \\
\text { surrounding the } \\
\text { site has resulted } \\
\text { in limitations on } \\
\text { the actual } \\
\text { industrial activity } \\
\text { that is } \\
\text { appropriate. A } \\
\text { progression from } \\
\text { residential to } \\
\text { mixed use is } \\
\text { more desirable. } \\
\text { Extremely small } \\
\text { amount of } \\
\text { employment land } \\
\text { proposed to be } \\
\text { converted. }\end{array}$ & $\begin{array}{l}\text { Residential } \\
\text { neighborhood } \\
\text { to the east and } \\
\text { light } \\
\text { industrial/com } \\
\text { mercial (auto } \\
\text { shops etc.) to } \\
\text { the west. }\end{array}$ \\
\hline $\begin{array}{l}(6) \\
\text { OP } 13 \\
113480\end{array}$ & $\begin{array}{l}\text { SW Corner } \\
404 \text { and } \\
407\end{array}$ & & $\begin{array}{l}\text { Municipal } \\
\text { Road }\end{array}$ & Industrial & Vacant & $\begin{array}{l}\text { New } \\
\text { convention } \\
\text { facility or }\end{array}$ & $\begin{array}{l}\text { Keeps some } \\
\text { employment } \\
\text { designations and }\end{array}$ & $\begin{array}{l}\text { Site is located } \\
\text { south of } \\
\text { Avenue } 7 \text { and }\end{array}$ \\
\hline
\end{tabular}




\begin{tabular}{|c|c|c|c|c|c|c|c|c|}
\hline & & & & & & $\begin{array}{l}\text { theatre + } \\
\text { mid/high rise } \\
\text { residential + } \\
\text { office + hotel. } \\
\text { Increase } \\
\text { density from } \\
90 \% \text { to } 209 \% \text {. }\end{array}$ & $\begin{array}{l}\text { intensifies } \\
\text { employment } \\
\text { uses through } \\
\text { office and hotel } \\
\text { development. } \\
\text { Mixed use } \\
\text { proposal is ideal } \\
\text { in response to } \\
\text { demographic } \\
\text { shifts (millennials } \\
\text { desiring amenity } \\
\text { rich spaces). } \\
\text { Transit } \\
\text { supportive, } \\
\text { mixed use node } \\
\text { seen as ideal on } \\
\text { this site. }\end{array}$ & $\begin{array}{l}\text { East of } \\
\text { Commerce } \\
\text { Valley drive } \\
\text { east. } \\
\text { Surrounded by } \\
\text { low density } \\
\text { commercial } \\
\text { and industrial } \\
\text { uses to the } \\
\text { south and the } \\
\text { west, with } \\
\text { designated } \\
\text { Open Space to } \\
\text { the east. }\end{array}$ \\
\hline $\begin{array}{l}(7) \\
\text { OP } 13 \\
114027\end{array}$ & $\begin{array}{l}\text { Warden } \\
\text { and Elgin } \\
\text { Mills }\end{array}$ & $\begin{array}{l}38.8 \\
\text { ha }\end{array}$ & $\begin{array}{l}\text { Regional } \\
\text { Road }\end{array}$ & $\begin{array}{l}\text { Agricultural and } \\
\text { Hazard Land }\end{array}$ & Farm & $\begin{array}{l}\text { Re-designate to } \\
\text { Commercial- } \\
\text { Corridor to } \\
\text { allow for } \\
\text { commercial + } \\
\text { residential + } \\
\text { employment. }\end{array}$ & $\begin{array}{l}\text { Proposed } \\
\text { employment } \\
\text { targets can be hit } \\
\text { on this land while } \\
\text { building } \\
\text { commercial / } \\
\text { residential at the } \\
\text { same time - in } \\
\text { the interest of } \\
\text { complete } \\
\text { communities. } \\
\text { Designating } \\
\text { strictly for Future } \\
\text { Employment } \\
\text { Uses is not in line } \\
\text { with provincial } \\
\text { policies of mixing } \\
\text { uses. Want to } \\
\text { rezone to a more } \\
\text { "open" } \\
\text { designation. }\end{array}$ & $\begin{array}{l}\text { Undeveloped } \\
\text { greenfields } \\
\text { surrounding the } \\
\text { site - part of } \\
\text { future the City's } \\
\text { future } \\
\text { development } \\
\text { areas. }\end{array}$ \\
\hline $\begin{array}{l}(8) \\
\text { OP } 13 \\
114066\end{array}$ & $\begin{array}{l}\text { South of } \\
\text { Elgin Mills, } \\
\text { between } \\
404 \text { and } \\
\text { Woodbineb } \\
\text { y-pass }\end{array}$ & $\begin{array}{l}18.5 \\
\text { ha }\end{array}$ & $\begin{array}{l}\text { Regional } \\
\text { Road } \\
\text { Municipal } \\
\text { Road }\end{array}$ & $\begin{array}{l}\text { Business Park } \\
\text { Area }\end{array}$ & Vacant & $\begin{array}{l}\text { Re-designate to } \\
\text { Commercial, } \\
\text { Community } \\
\text { Amenity - } \\
\text { Business Area } \\
\text { for residential } \\
+ \text { employment } \\
\text { mixed use. } \\
\text { Essentially } \\
\text { looking to } \\
\text { expand the } \\
\text { current uses } \\
\text { allowed by } \\
\text { applying the } \\
\text { Commercial } \\
\text { designation. }\end{array}$ & $\begin{array}{l}\text { Existing } \\
\text { employment } \\
\text { designation is } \\
\text { too rigid and } \\
\text { does not allow } \\
\text { for complete } \\
\text { communities as } \\
\text { per Provincial } \\
\text { Policy. The } \\
\text { market is } \\
\text { dictating flexible, } \\
\text { amenity rich } \\
\text { employment } \\
\text { spaces, not } \\
\text { traditional ELE. }\end{array}$ & $\begin{array}{l}\text { Site lies in } \\
\text { between } \\
\text { Highway } 404 \\
\text { (to the west) } \\
\text { and the } \\
\text { Cathedraltown } \\
\text { residential } \\
\text { neighborhood } \\
\text { to the east. }\end{array}$ \\
\hline $\begin{array}{l}(9) \\
\text { OP } 13 \\
114950\end{array}$ & $\begin{array}{l}\text { Woodbine } \\
\text { Road and } \\
\text { Markland } \\
\text { Street }\end{array}$ & $\begin{array}{l}1.6 \\
\text { ha }\end{array}$ & & Business Park & $\begin{array}{l}\text { Vacant } \\
\text { greenfield }\end{array}$ & $\begin{array}{l}\text { Re-designate } \\
\text { from industrial } \\
\text { to residential } \\
\text { mid, low-rise. }\end{array}$ & $\begin{array}{l}\text { To align site with } \\
\text { surrounding land } \\
\text { use context. The } \\
\text { existing } \\
\text { permitted uses } \\
\text { are not } \\
\text { compatible with } \\
\text { the already built } \\
\text { development } \\
\text { surrounding the } \\
\text { site. Loss of } \\
\text { employment } \\
\text { could be made } \\
\text { up by intensifying } \\
\text { other } \\
\text { employment } \\
\text { areas close by. } \\
\text { Different housing } \\
\text { units increase } \\
\text { stock diversity in } \\
\text { the City. }\end{array}$ & $\begin{array}{l}\text { Site abuts a low } \\
\text { density } \\
\text { residential } \\
\text { neighborhood } \\
\text { to the north, } \\
\text { with mostly } \\
\text { vacant but } \\
\text { designated } \\
\text { employment } \\
\text { lands to the } \\
\text { south, west and } \\
\text { east. }\end{array}$ \\
\hline $\begin{array}{l}(10) \\
\text { OP } 13 \\
116651\end{array}$ & $\begin{array}{l}\text { North of } \\
\text { Elgin Mills } \\
\text { West of } \\
\text { Woodbine } \\
\text { By-pass }\end{array}$ & 6 ha & $\begin{array}{l}\text { Municipal } \\
\text { Road }\end{array}$ & Industrial & Vacant & $\begin{array}{l}\text { To re-designate } \\
\text { the site to } \\
\text { urban } \\
\text { residential and } \\
\text { commercial. } \\
\text { Proposal } \\
\text { involves a } \\
\text { combination of } \\
\text { single } \\
\text { detached, } \\
\text { street } \\
\text { townhouse, } \\
\text { rear lane } \\
\text { townhouses, } \\
\text { and two storey } \\
\text { mixed use } \\
\text { office building } \\
\text { with retail at } \\
\text { grade. }\end{array}$ & $\begin{array}{l}\text { Current Industrial } \\
\text { designation is } \\
\text { not suitable for } \\
\text { the lands- } \\
\text { opinion is that } \\
\text { they will never be } \\
\text { developed for } \\
\text { industrial } \\
\text { purposes. Site } \\
\text { not seen as } \\
\text { marketable - } \\
\text { other sites in the } \\
\text { city are more } \\
\text { attractive } \\
\text { industrial uses. } \\
\text { The proposal will } \\
\text { diversify housing } \\
\text { choices for } \\
\text { consumers in }\end{array}$ & $\begin{array}{l}\text { Vacant } \\
\text { greenfield area } \\
\text { that lies } \\
\text { adjacent to low } \\
\text { density } \\
\text { residential } \\
\text { community to } \\
\text { the east. }\end{array}$ \\
\hline
\end{tabular}




\begin{tabular}{|c|c|c|c|c|c|c|c|c|}
\hline & & & & & & & $\begin{array}{l}\text { Markham. Site } \\
\text { has an } \\
\text { Environmental } \\
\text { Protection Area } \\
\text { (woodlot) } \\
\text { adjacent to it, } \\
\text { which makes it } \\
\text { more conducive } \\
\text { to residential. }\end{array}$ & \\
\hline $\begin{array}{l}(11) \\
\text { OP 13 } \\
116842\end{array}$ & $\begin{array}{l}\text { Woodbine } \\
\text { and } 19^{\text {th }} \\
\text { Ave }\end{array}$ & $\begin{array}{l}40 \\
\text { ha }\end{array}$ & $\begin{array}{l}\text { Municipal } \\
\text { Road }\end{array}$ & $\begin{array}{l}\text { Agricultural + } \\
\text { Hazard Land }\end{array}$ & & $\begin{array}{l}\text { Re-designate to } \\
\text { "Industrial" to } \\
\text { facilitate the } \\
\text { development of } \\
\text { a cemetery. }\end{array}$ & $\begin{array}{l}\text { In line with PPS } \\
\text { in that it } \\
\text { proposes a } \\
\text { cemetery within } \\
\text { the urban } \\
\text { boundary and } \\
\text { not on prime } \\
\text { agricultural land. } \\
\text { The proposed } \\
\text { cemetery meets } \\
\text { the needs of the } \\
\text { large Roman } \\
\text { Catholic } \\
\text { population in } \\
\text { Markham and } \\
\text { provides } \\
\text { affordable burial } \\
\text { options. This } \\
\text { location would } \\
\text { require minimal } \\
\text { municipal } \\
\text { servicing } \\
\text { enhancements } \\
\text { as well. }\end{array}$ & $\begin{array}{l}\text { Surrounded by } \\
\text { undeveloped } \\
\text { greenfield / } \\
\text { farmland. }\end{array}$ \\
\hline $\begin{array}{l}(12) \\
\text { OP 13 } \\
131100\end{array}$ & $\begin{array}{l}\text { Highway } 7 \\
\text { E and } \\
\text { South Park }\end{array}$ & $\begin{array}{l}\text { Two } \\
\text { parc } \\
\text { els- } \\
\text { roug } \\
\text { hly } \\
5.5 \\
\text { ha } \\
\text { each }\end{array}$ & $\begin{array}{l}\text { Municipal } \\
\text { road / } \\
\text { Regional } \\
\text { Road }\end{array}$ & $\begin{array}{l}\text { Industrial + } \\
\text { Future Urban } \\
\text { Area }\end{array}$ & Office Uses & $\begin{array}{l}\text { To re-designate } \\
\text { to allow for } \\
\text { mixed use } \\
\text { development } \\
\text { including } \\
2,762 \\
\text { apartment } \\
\text { units, } 68 \\
\text { townhouse } \\
\text { units, } \\
11,800 \mathrm{~m} 2 \text { o } \\
\text { retail space, } \\
7,710 \mathrm{~m} 2 \text { of } \\
\text { office space. }\end{array}$ & $\begin{array}{l}\text { The proposal } \\
\text { helps the City } \\
\text { meet its } \\
\text { intensification } \\
\text { targets while } \\
\text { providing a } \\
\text { balanced } \\
\text { housing supply. } \\
\text { The site location } \\
\text { renders it at a } \\
\text { competitive } \\
\text { disadvantage as } \\
\text { it is separated } \\
\text { from local ELE } \\
\text { node. Loss in } \\
\text { employment here } \\
\text { can be made up } \\
\text { for on other } \\
\text { future sites. }\end{array}$ & $\begin{array}{l}\text { Site lies } \\
\text { immediately } \\
\text { south of } \\
\text { Avenue } 7 \text { and } \\
\text { north of } \\
\text { Highway } 407 . \\
\text { Abuts newly } \\
\text { constructed } \\
\text { residential } \\
\text { developments } \\
\text { (townhouse } \\
\text { +condominium } \\
\text { s), which lie to } \\
\text { the east of the } \\
\text { subject site. }\end{array}$ \\
\hline
\end{tabular}




\section{References}

Alamenciak, T. (2013). Density in Toronto: Where to work when condo's target industrial sites?. The Toronto Star. Retrieved from:

http://www.thestar.com/news/gta/2012/11/08/density_toronto_where_to_work_when_co ndos_target_industrial_sites.html

Augusta National Inc. (2013). Growth Plan/Markham Official Plan Employment Conversion Criteria Needs and Justification Report- Holy Rosary Cemetery. Unionville.

Boswell, M., Greve, A., \& Seale, T. (2010). An assessment of the link between greenhouse gas emissions inventories and climate action plans. Journal of the American Planning Association 76(4), 451-462.

Bousfields Inc. (2009). Applications for Official Plan and Zoning By-law Amendments, Woodbine International Centre, 9390 Woodbine Avenue, Northwest Corner of Woodbine Avenue and Markland Street. Toronto.

Bousfields Inc. (2012). Planning Rationale: Proposed Official Plan Amendment Lindvest Properties (Cornell) Limited. Toronto.

Canada Mortgage and Housing Corporation. (2013). Residential Intensification Case Studies: The Kings Regeneration Initiative. Retrieved from: http://www.cmhcschl.gc.ca/en/inpr/su/sucopl/upload/The-Kings-Regeneration-Initiative-Toronto-Ont.pdf. 
Canadian Federation of Independent Business (2010). The Tale of Two Tax Rates: How Ontario and its Municipalities Tax Business Properties. Retrieved from: http://www.cfibfcei.ca/cfib-documents/on0465.pdf

Canadian Urban Institute. (2011). The New Geography of Office Location and the Consequences of Business as Usual in the GTA. Toronto. http://www.canurb.com/doc_download/8-the-new-geography-of-office-location-and-theconsequences-of-business-as-usual-in-the-gta.

Canadian Urban Institute. (2013) Strategic Regional Research: A Region in Transition. Toronto. Retrieved from:

http://www.cbc.ca/toronto/features/stuckintraffic/docs/transition.pdf

City of Markham. (2013). City of Markham Official Plan Part 1.

City of Markham (2013). Draft Official Plan 2012 - Employment Conversion and Redesignation Applications Report to Development Services Committee.

City of Markham (2013). Economic Profile: Mid-year 2013. Economic Development Department. Retrieved from: http://www.markham.ca

Centre for Urban Growth and Renewal, The. (2012). Strong Neighbourhoods and Complete Communities: a New Approach to Zoning for Apartment Neighbourhoods. Retrieved from: 
http://www.unitedwaytoronto.com/downloads/whatWeDo/reports/UWT-Zoning-Report20120921.pdf

Gagnon and Law Ltd. (2013). Comprehensive Official Plan Review, Public Input, Official Plan Amendment Application.

Green Leigh, N. G. and Holziel, N. (2012) "Sustainable Cities Need Industrial Land", Journal of the American Planning Association, 78(1).

Hemson Consulting Ltd. (2008). Employment Land Review Study: City of Mississauga.

Hsieh, H. and Shannon, S. (2005). Three Approaches to Qualitative Content Analysis. Qualitative Health Research 15(9).

Janzen, K. (2012). Five Perspectives: The Employment Lands Challenge. Novae Res Urbis, Greater Toronto Area Edition. Volume 15 (16).

KLM Planning Partners Inc. (2013). Justification Statement, Condor Acquisition Inc. Official Plan Amendment.

Malone Given Parsons (2012) Sustainable Competitive Advantage and Prosperity: Planning for Empl

Malone Given Parsons Ltd. (2013). Planning and Needs Justification Box Grove Sites A \&B. 
Malone Given Parsons Ltd. (2013). Planning Needs and Justification Report: Leitchcroft.

Neptis Foundation (2013). Implementing the Growth Plan for the Greater Golden Horseshoe: Has the Strategic Regional Vision Been Compromised?. Retrieved from: http://www.neptis.org/sites/default/files/historical_commentary/historicalcomm_web_200 711291.pdf

Neptis Foundation. (2006). Commentary on the Ontario Government's Proposed Growth Plan for the Greater Golden Horseshoe. Revised Edition. Toronto. Retrieved from: http://www.neptis.org/sites/default/files/growth_plan/neptis_gpcommentary_revised_web _24mar_20062.pdf

Ontario Municipal Board (2006). St Johns McNicol Centre vs. the City of Toronto. Retrieved from: http://www.omb.gov.on.ca/english/eDecisions/eDecisions.html

Ontario Municipal Board (2009). Smartcentres and Toronto Film Studios vs. City of Toronto. Retrieved from: http://www.omb.gov.on.ca/english/eDecisions/eDecisions.html

Ottensman, J. (2005). Planning through the Exchange of Rights Under Perfromance Zoning. Institute of Economic Affairs. December 2005. Oxford.

Pendall, R., Puentes, R., and Martin, J. (2006) From Traditional to Reformed: 
Review of the Land Use Regulations in the Nation's Largest Metropolitan Areas. Washington DC: Brookings Institution.

Province of Onatrio. (2014) Provincial Policy Statement.

Province of Ontario. (2006) Places to Grow: Better Choices, Brighter Future:Growth Plan for the Greater Golden Horseshoe.

Province of Ontario. (2008) Planning for Employment in the Greater Golden Horseshoe. Toronto: Ministry of Infrastructure Renewal.

Retzlaff, R. (2008). “Green Building Assessment Systems”. Journal of the American Planning Association. 74(4).

Richmond Regional Planning District Commission (2001). Applications for Performance Zoning for Industrial Uses in Hannover County: A Technical Assistance Report.

RJ Forhan \& Associates (2013). Planning Justification Report in support of Official Plan Amendment for Snider Farm, Romandale Farms Ltd.

RJ Forhan \& Associates. (2013). Planning Justification Report in support of Official Plan Amendment for Cathedral Town Ltd. 
Slack, Enid. (2002) “Property Tax Reform in Ontario: What have we Learned?”, Canadian Tax Journal, 50(2).

Stanford, J. (2013). Don't turn factories into cookie cutter condos. The Globe and Mail.

Retrieved from: http://www.theglobeandmail.com/globe-debate/dont-turn-factories-intocookie-cutter-condos/article7882707/

Statistics Canada. (2013). Population and dwelling counts, for Canada and census subdivisions (municipalities), 2011 and 2006 censuses. Retrieved from: http://www12.statcan.gc.ca/census-recensement/2011/dp-pd/hlt-fst/pd-pl/TableTableau.cfm? $\mathrm{LANG}=$ Eng $\& \mathrm{~T}=301 \& S=3 \& 0=\mathrm{D}$

Taylor, Z and van Nostrand, J. (2008) Shaping the Toronto Region, Past, Present and Future. Toronto: Neptis Foundation.

Tran, H. (2011). Industrial diversity and economic performance: A spatial analysis. (Doctoral dissertation). The University of Nebraska - Lincoln.

Watson and Associates (2011). City of Barrie Growth Management Strategy: Employment Lands Municipal Comprehensive Review Phase 3. 